\title{
Improving Learning Motivation and the Ability to Organism Categorize with Think Pair Share Learning Model
}

\author{
Ayel Robbul Barokah ${ }^{1, *}$ Setya Raharja ${ }^{2}$ \\ ${ }^{1}$ Master of Educational Management, Faculty of Education, Universitas Negeri Yogyakarta, Indonesia \\ ${ }^{2}$ Department of Educational Management, Faculty of Education, Universitas Negeri Yogyakarta, Indonesia \\ *Corresponding author. Email: ayelrobbul.2018@student.uny.ac.id
}

\begin{abstract}
The purpose of This study to create an effective learning model about organisms categorized to foster motivation and improved students' abilities in the learning process on organism things classification material through the application of the Think Pair and Share type learning model. This research was motivated by the lack of learning models used by teachers, resulting in students not understanding the learning material described and resulting in student learning outcomes are less than the specified minimum completeness criteria. This type of research is classroom action research and is carried out in two learning cycles. The subjects of this research were 32 students. Instruments which is used in this research were observation sheets and questionnaires and also tests. Observation sheets and questionnaires were used to learn the implementation of Think Pair Share learning models and tests to measure the ability of students in categorizing the organism things. Data collection techniques using test and nontest. The data analysis technique used is quantitative descriptive data analysis. The results showed an increase in the observation cycle of learning motivation of the first cycle students as a whole by $67.34 \%$ and the observation sheet of the second cycle increased to $88.69 \%$. While the results of students' ability to categorize organism things in the first cycle were $75.26 \%$ and the second cycle increased with an average value of student learning outcomes $82.28 \%$.
\end{abstract}

Keywords: Learning motivation, Analysis ability, Think pair and share.

\section{INTRODUCTION}

Based on the results of observations made on February 13, 2019, in one of Yogyakarta's junior high schools, the learning process using the ongoing lecture method tends to be passive. This is evidenced by the existence of data when learning natural science, on average only a quarter of the total number of students, namely 10 out of 32 students who express their opinions and are active and follow the explanations from the teacher well or are motivated to learn. The majority of students also still answer questions with textbooks or read books instead of their understanding. Besides, students still think that natural science is categorized as a difficult subject to understand because of the many scientific names that students think must be memorized. The result of this assumption causes students to feel lazy to follow lessons and do the assignments given by the teacher.
This observation was also supported by the results of an interview with a natural science teacher on February 13, 2019, which obtained data that students in the class were not enthusiastic about taking part in the ongoing learning. The passive learning model used lectures, making students only listen and be silent, this can result in a decrease in student learning outcomes, which is by the research results of [1] which results in a decrease in learning outcomes the result of passive learning.

Even when the teacher asked them if they understood the material presented, they were just silent. Thus, teachers assume that they have mastered the material well. However, this was not by the results of the students' daily test scores which were still low and below the completeness standard set by the school. The average daily test results obtained by students were 63.12 and almost $60 \%$ of the 32 students scored 
below 60. This is also influenced by the attitude of students who do not want to find difficulties in learning, students do not like to try hard so that the role of the teacher as a guide is needed. The lack of empowerment in students' abilities in the learning process results in a lack of strengthening a learning, learning objectives, and student learning persistence in participating in the learning process so that it has an impact on decreasing student learning motivation. This is in line with the results of research from [2] who suggest that student motivation and learning outcomes are one unit that must be maintained to produce superior students.

After the analysis was carried out, it turned out that the causative factor was the learning model which tended to be passive and very boring because only 2 models were used, namely lectures and questions and answers. Thus, it is necessary to make efforts to improve the learning model used by using certain learning models which are also adapted to the character of the learning material.

According to [3] learning outcomes are a mental development that occurs after the learning process. This mental development manifests itself in the cognitive, affective, and psychomotor types. The learning outcomes referred to in this study are the students' final ability after taking the process of learning activities of natural science subjects on the classification of organism things which is tested through an ability test that leads to the ability to categorize organism things. The Think Pair and Share type learning model has a special learning structure designed to influence student interaction patterns in working together, complementing, and interdependence in study groups in the learning process [4]. Think Pair and Share learning is a structured learning model and aims to improve student cooperation and develop students' thinking skills to find solutions to problems faced in learning [5].

The material for the classification of organism things is categorized by the majority of students as difficult learning material because it includes various classifications of organism things that are difficult to understand. Therefore, the application of the Think Pair and Share type cooperative learning model is expected to overcome the problems experienced by students, because the learning model is by the character of the learning material.

Based on the analysis of the problems that have been described, the researcher argues that research on the application of the Think Pair and Share learning model to the classification of organism things needs to be done to increase motivation and student learning outcomes so that students can carry out the learning process actively and student learning outcomes get results the good one. The type of think pair share cooperative learning model has a better effect on student learning outcomes than other types of cooperative learning models. These results are attributed to the think pair share a cooperative learning model. Students learn not only by memorizing the material, but students learn by exchanging information with their friends. This statement is supported by the results of research [6] with the title "The influence of the think pair share type of cooperative learning model on the mathematics learning outcomes of class VIII students of SMPN 17 Bengkulu City" which results in that the think pair share type of cooperative learning is more effective than other types of cooperative learning.

\section{METHOD}

This type of research is classroom action research (CAR). Classroom action research is research based on the main problems that occur in class. The research setting was carried out in one of the class VII C junior high schools in Yogyakarta. The learning material setting takes place in 2 cycles $(6 \times 45$ minutes). The material for the classification of organism things presented in the learning process using the Think Pair and Share model is Kingdom Animalia subphylum Invertebrate and subphylum Vertebrate. This research was conducted by collaborating or working with class teachers. The learning methods are discussion, question and answer, and presentation. The setting of the learning process is carried out in the classroom.

In the learning process in each action cycle, the role of the teacher is the researcher, and 32 students including 14 male students and 18 female junior high school students class VII C are the subjects of this study. This study, using two variables, namely the free variable and the bound variable. The independent variable or variable $\mathrm{X}$ is the think pair share (x), learning model. While the dependent variable or variable $\mathrm{Y}$ is an increase in the achievement of learning outcomes (y). Increasing learning achievement by using the think pair share learning model is said to be successful if the student's score is above the specified minimum completeness criteria, namely 75 .

The instrument that will be used in this research is a test in the form of multiple-choice questions and observation sheets. Instrument test that contains questions whose answers have a certain standard answer, true-false, or answer scale. The question instrument used was multiple-choice questions. While 
the observation data were obtained using the observation sheet of observations on the motivation and implementation of the learning process which was carried out directly on the students during the learning activities in class. Observed data obtained in the form of a score of "Yes" given a score of 1 and "No" given a score of 0 . If the student takes action as written on the observation sheet, it is marked with the word "Yes", on the other hand, if the student does not take action as written on the observation sheet then it is marked with the word "No".

The research data were analyzed descriptively. The data analysis on each research instrument, namely the analysis of multiple-choice test questions as a means of evaluating the cognitive domain and analyzing the observation of student learning motivation. Analysis of multiple-choice test questions as a means of evaluating the cognitive domain of data used to measure the achievement of biology learning outcomes, namely test value data. Test data can be analyzed to determine the cognitive domain of students in learning in each cycle. To determine the increase in students' cognitive abilities is done by comparing the average score of the previous year's test results with the results in each cycle. The way to analyze it has been determined, namely based on:

$\mathrm{M}=\frac{\Sigma \mathrm{x}}{\mathbf{N}}$

Information:

$\mathrm{M}=$ Mean (average value) .

$\Sigma \mathrm{x}=$ The total value obtained from the sum of the scores for each individual.

$\mathrm{N}=$ That is individual [7].

While the analysis of the observation of student learning motivation. Student motivation research data is contained in the observation sheet (observation). The observation sheet for assessment uses the Guttman scale, namely using a checklist $(\checkmark)$. For "yes" answers, a checklist is given $(\checkmark)$ and for "no" answers, it is left blank. The percentage of each indicator is calculated using the following formula

$\mathrm{P}=\frac{\mathrm{f}}{\mathrm{N}} \times 100 \%$

Information:

$\mathrm{f} \quad=$ Is a presentation of learning observation scores.

$\mathrm{N}=$ try to score the number of scores achieved in each cycle.

$\mathrm{P} \quad=$ Maximum score [8].
The classroom action research design used in this study was the spiral classroom action model developed by Kemmis and Tangart in [9] while the stages are as by:

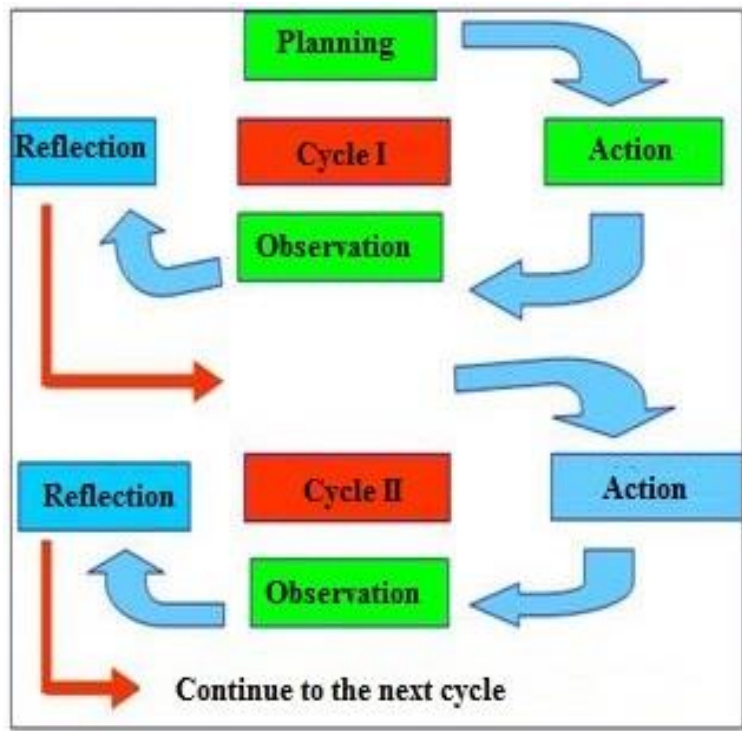

Figure 1 The spiral class action flow

\subsection{Planning}

Planning includes activities in which the researcher collaborates with the teacher to make a learning implementation plan for the classification of organism things, the learning implementation plan includes preliminary activities by providing perceptions so that students understand the indicators and learning objectives, then the core activities which include providing stimulation (stimulation) which aims to make students analyze by thinking independently, (pairing) in pairs with group friends to discuss answers, (sharing) sharing with classmates on the results of the discussion and closing activities the teacher guides the results of the discussion. After the researcher prepared the learning activity design, the researcher prepared the learning material and made a research instrument in the form of test questions which included multiple-choice questions and essays. The grid in making the multiple-choice question instrument, namely students mentioning, selecting, determining the basis for the classification of organism things, and making the essay instrument students explain, distinguish, describe and sort various types of animals based on their characteristics. Then the researcher made an observation sheet to determine student learning motivation during the learning process. 


\subsection{Action}

This research activity consists of pre-action and action activities, in pre-action activities, researchers who act as teachers of the learning process conduct socialization about how the implementation of learning activities uses the Think Pair Share learning model used in learning material classification of organism things so that students can understand the tasks which are carried out in the learning process. Furthermore, after the pre-action activities, there are action activities, where the implementation of the action is carried out by the planned learning activity design. In implementing this action the researcher observes and is involved in the learning process. When researchers become student facilitators, the teacher acts as an observer in charge of gathering information from the learning that is taking place and vice versa.

\subsection{Observation}

Observation activities are carried out by observing the learning activities of organism things classification material that are taking place, this is done by the observer and the teacher by using the observation sheet that has been made. In this process, three observers assisted the researchers.

\subsection{Reflection}

Activities at the reflection stage are carried out collaboratively, where the researcher and the teacher discuss the learning process and student learning outcomes. If there are deficiencies in the learning process in cycle I, then these deficiencies can be taken into consideration in improving the next cycle of research. The decision to stop or continue the research is determined by the results if one group of students has not mastered the material in using the Think Pair and Share learning model [10].

\section{RESULT AND DISCUSSION}

Based on the research conducted, the researcher obtained research data that included data on student learning outcomes at the end of each cycle through the Think Pair and Share learning model. The results of the cycles I and II can be seen in table 1 .

Based on the average results of the observation sheets during the learning process, the students actively respond and listen when the teacher gives apperception and direction. This can be seen from the results of the observation data, namely students follow the teacher's direction by sitting by the group that has been determined by the teacher, conducting discussions and students succeed in explaining the results of group discussions about the cases given by the teacher.

Table 1. Average student learning motivation

\begin{tabular}{|c|c|c|}
\hline $\begin{array}{c}\text { Student } \\
\text { Motivation To } \\
\text { Study }\end{array}$ & $\begin{array}{c}\text { Observation } \\
\text { Result }\end{array}$ & $\begin{array}{c}\text { Success } \\
\text { Indicators }\end{array}$ \\
\hline Cycle I & 67.34 & $>70$ \\
\hline Cycle II & 88.69 & $>70$ \\
\hline
\end{tabular}

Based on the results of the observation in cycle I, the lowest number of scores was at the conceptualization stage, namely the indicators of students concluding learning outcomes, this happened because some students did not carry out activities according to the observation sheet during the learning process. After all, they talked alone or were busy with their respective activities. Whereas in cycle II, based on the results of observations, it was found that the student observation sheets had an increase from the first cycle, namely the average result of the observation sheet in cycle II reached $88.69 \%$ compared to the first cycle, namely $67.34 \%$. This result means that the implementation of student learning has followed the learning process well and is by the syntax of the Think Pair and Share learning model.

The results of students 'natural science learning in cycles I and II were obtained from the results of the students' work in completing the post-test as many as 15 multiple choice questions on the classification material of living things, especially the subphylum invertebrates and vertebrates. The minimum completeness criteria standard that has been set by the school is 75 and the learning outcomes of class VII C students can be seen in the table 2 .

Table 2. Post test results

\begin{tabular}{|c|c|c|c|c|}
\hline $\begin{array}{c}\text { Post Test } \\
\text { Results }\end{array}$ & $\begin{array}{c}\text { Acquisition } \\
\text { of Student } \\
\text { Value }\end{array}$ & $\begin{array}{c}\text { Percentage } \\
\text { of Total } \\
\text { Students (\%) }\end{array}$ & Average \\
\cline { 2 - 4 } & \multicolumn{2}{|c|}{ Value } \\
\hline Cycle I & 12 & $\geq 75$ & 39 & \multirow{2}{*}{75.26} \\
\cline { 2 - 4 } & & 19 & 61 & \multirow{2}{*}{82.28} \\
\hline Cycle II & 3 & & 10 & \\
\cline { 2 - 4 } & & 29 & 90 & \\
\hline
\end{tabular}

Based on the data from the results of the post-test score in cycle I, it can be seen that 19 students have 
reached the minimum completeness criteria, and 12 students have not reached the minimum completeness criteria set by the school. Whereas in the post-test result value in cycle II, there was an increase in the number of students who reached the minimum completeness criteria, namely 29 students and who had not reached the minimum completeness criteria of 3 students. Based on the observation data on learning motivation and student learning outcomes using the Think Pair and Share learning model, it can be agreed that this classroom action research will not be continued in the next cycle. This is because the learning process has increased which is indicated by the average score of the post-test results of students in cycle I which is still lacking and has increased in cycle II. Thus the classroom action research process can be stopped in cycle II.

Classroom action research using the Think Pair and Share learning model in the material classification of organism things in general aims to improve the ability to categorize organism things and increase student motivation in learning. The use of the Think Pair and Share learning model in this study was carried out as an effort to improve and enhance the learning process in class VII $\mathrm{C}$ because the Think Pair and Share learning model has the characteristics to make a learning process that is initially passive active. Pair thinking and sharing learning models are used in class VII C so that students can directly follow and understand the learning material. The teacher prepares things in the learning process which includes the preparation of a lesson plan, materials, pictures to provide stimulation accompanied by questions and post-test questions. The following is a bar diagram of the comparison of the results of the natural science learning process in cycle I and cycle II of class VII C on the classification of organism things using the Think Pair and Share learning model:

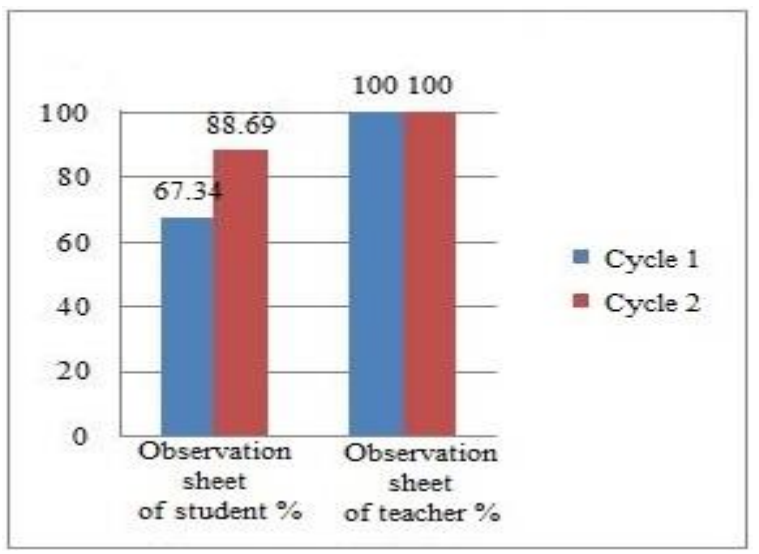

Figure 2 Diagram comparison of student learning motivation results cycle I and cycle II
The learning process carried out in class VII $\mathrm{C}$ in cycle I was carried out in one meeting, with the number of students who took part in the learning, namely 31 students. Overall students are active in group discussions, but there are some students in small groups who are less active and still talk to themselves in the learning process. Three observers observed student learning activities. Based on data from observations that have been made, the average percentage of the student learning process is $67.34 \%$. This means that there are still students who are not motivated in the learning process and do not carry out the learning process by the syntax of the Think Pair and Share learning model.

Think Pair and Share type learning examines students to explore individual and group thoughts on the topic of classification material for organism things and guides students to think broadly in discussions to share knowledge with other students. This is in line with the results of research from [11] where discussions in an active learning process can help improve the character of students or students become more independent in finding and managing information about the material learned to learn. Activeness in student discussion can make students better at interacting between students because students can apply their knowledge to share with other students, this can help support the development of student learning outcomes

The learning process using the Think Pair and Share learning model in cycle I have not resulted in the expected development. The average value of student learning outcomes in cycle I was $75.26 \%$, where there were only 19 out of 31 students who had a classical completeness score of $61 \%$ and the results of these scores had not yet reached the classical completeness criteria expected by the school. This is caused by several good factors in student discussion interactions, lack of understanding of learning materials, students are not careful in answering post-test questions and students are not accustomed to using the Think Pair and Share learning model which makes the ability to categorize students to the material classification of organism things is still low.

The teacher plays an important role in the learning process. According to [12] the role of the teacher can be carried out well if it is done with a good learning design in the learning process because the learning process contains a series of student interactions that are related to the learning interactions provided by the teacher, this is based on the reciprocal relationship carried out in educational situations for achieving learning goals. This explanation is by the results of 
research by [13] which resulted in the interaction of reciprocal relationships between teachers and students as an important foundation of learning in achieving the main goals of education.

The learning process using the Think Pair and Share learning model in cycle II on the ability to organism categorize of analyzing and shows an improvement in student learning outcomes and the learning model applied is going well and according to its syntax, this can be seen from the average post-test score. students. Cycle II, the number of students who took part in the learning was 32 students. Students who get a post-test score reaching classroom action research (CAR) determined by the school are 29 students, in other words, students who score $\geq 75$ reaches $90 \%$. This is by the explanation of [14] which explains that in the learning process using the discussion method will have better results than conventional learning and can improve student learning outcomes because students are calmer and enjoy the lessons given. Overall, student learning outcomes in cycle I and cycle II class VII C using the Think Pair and Share learning model can be illustrated using a bar chart as follows:

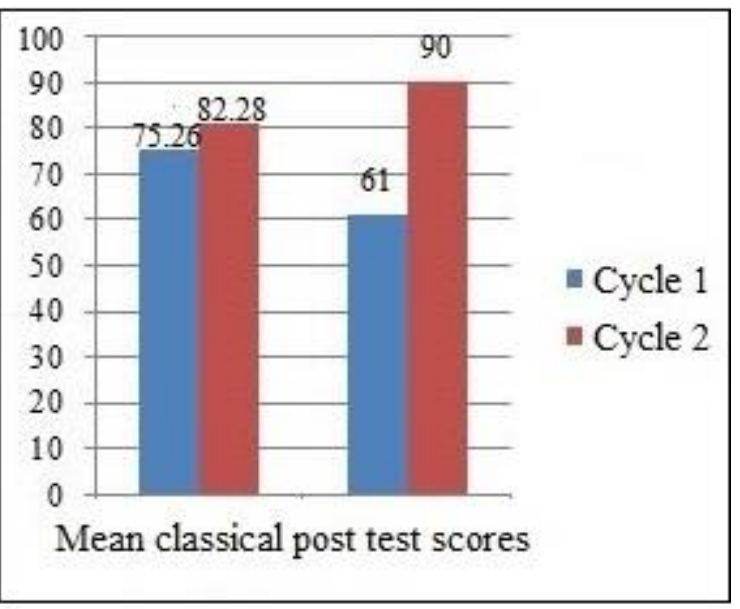

Figure 3 Diagram of student learning outcomes

Based on the diagram of the comparison of student learning outcomes in cycles I and II, it can be seen that the average value of student learning outcomes in cycle I am $75.26 \%$ while in cycle II has increased to $82.28 \%$. The process of increasing natural science learning outcomes in the two cycles that occur shows that the process of improving learning that is carried out when completing the first cycle of learning can be by the indicators needed by students to improve learning outcomes. In the second cycle students who achieved the minimum completeness criteria set by the school scored $\geq 75$ reaching $82.28 \%$.
This is by the results of research conducted by [15], [16] and [17] which resulted that active learning using the Think Pair and Share learning model can obtain better learning outcomes when compared to the use of lecture learning models. given to students. This is also in line with research conducted by [18], [19] and [20] which resulted in the Think Pair and Share learning model so far is still very effective in changing the passive learning paradigm and this can have consequences. in improving learning outcomes and analytical skills and student motivation.

Based on this analysis, the learning that took place in class VII C of Yogyakarta junior high school by applying the Think Pair and Share type learning model was successful in increasing students' learning motivation and analytical skills in organism categorizing things. This can be seen from the results of the observation cycle II where the teacher who initially did passive learning was able to master the class well and carried out active learning guidance through cooperative learning methods to make the conditions in learning that took place conducive. The conducive learning conditions make students high in enthusiasm for learning, students can discuss well, respond to teacher learning in every activity and students begin to be skilled in analyzing the classification of organism things, this has an impact on the value of student learning outcomes which has increased when compared to using the lecture learning method. Therefore, classroom action research is stopped in syllabus II, and the application of the Think Pair and Share learning model to the classification of organism things can be said to be successful in increasing learning motivation and the ability to organism categorize beings in class VII C.

\section{CONCLUSION}

Based on the results of the research that has been done, it can be concluded that class VII C learning by applying the Think Pair Share learning model in natural science learning material classification of living things has been successfully carried out based on increased learning motivation and the ability to categorize students can be achieved through 2 learning cycles. The increase in student learning motivation as measured using the observation sheet learning motivation in the first cycle was $67.34 \%$ and the observation sheet in the second cycle increased by $88.69 \%$. While the increase in the ability to categorize students' living things was measured using post-test questions in the first cycle with an average student learning outcomes of $75.26 \%$ and the second cycle had an increase with an average value of student learning 
outcomes of $82.28 \%$. Based on the results of the research that has been carried out, the following suggestions are proposed, namely, for the education office, this research can be used as a material in the formulation of learning model policies, especially in improving teacher performance and student learning outcomes. Suggestions for school institutions and teachers, namely in the selection of teacher learning models, it is recommended to see the characteristics of the learning material so that the learning model and learning material can match the competence of learning objectives. As for the class and teachers studied, the Think Pair and Share type of learning model can be used as a source of new learning variations to increase student motivation and analytical skills.

\section{AUTHORS' CONTRIBUTIONS}

The author's contribution in this study is to propose and direct the improvement of learning models that are suitable for existing problems in class by paying attention to the learning model that is suitable for the ongoing subject. Because these problems are a key point in achieving learning objectives. Where at first the school using the lecture method could not produce good learning and students were bored in learning, by using the right method, namely think pair share, students would certainly be more active and learning in class was very enjoyable, so that student learning outcomes could reach the criteria determined by the school, this can be seen from the results of this study and various kinds of previous studies that we have discussed. This think pair share learning method is very suitable for learning natural science, because in natural science learning students are required to be able to interact and observe an object or animal directly and share knowledge with their friends.

\section{ACKNOWLEDGMENTS}

I would like to express my gratitude to the entire academic community of the Imogiri 1 Public Junior High School for assisting researchers in retrieving data so that researchers have no difficulty getting to the completion of this journal.

\section{REFERENCES}

[1] Darsono, The influence of cooperative learning model of think pair square with problem posing task on students' mathematics learning outcome, in: Proceedings of the 1st International Conference on Education Innovation, vol. 173, Atlantis Press, Amsterdam, 2018, pp. 78-81. DOI: https://doi.org/10.2991/icei-17.2018.21
[2] J. Darmawati, Pengaruh Motivasi Belajar Terhadap Prestasi Belajar Ekonomi Siswa SMA Negeri di Kota Tuban, Jurnal Ekonomi Pendidikan dan Kewirausahaan 3(1) (2013) 7990. DOI: http://dx.doi.org/10.26740/jepk.v1n1.p79-90

[3] J. Wu, Y. Yan, Study of humanity teaching model in higher vocational school Chinese teaching, in: Proceedings of the $4^{\text {th }}$ International Conference on Management Science, Education Tecnology, Arts, Social Science and Economics, vol. 85, Atlantis Press, Amsterdam, 2016, pp. 1855-1858. DOI: https://doi.org/10.2991/msetasse$\underline{16.2016 .417}$

[4] A.O. Bamiro, Effects of Guided Discovery and Think Pair Share Strategies on Secondary School Students Achievement in Chemistry, Sage Open 5(1) $2015 \quad 1-7 . \quad$ DOI: https://doi.org/10.1177/2158244014564754

[5] K.F. Nurazizah, W. Wuryandari, Pengaruh Model Kooperatif Tipe Think Pair Share Terhadap Kerja Sama Siswa, Jurnal Civis: Media Kajian Kewarganegaraan 16(1) 2019 80-88. DOI: https://doi.org/10.21831/jc.v16i1.21520

[6] A.E. Wiranti, Z. Rafli, Darmahusni, Discussion and Think Pair Share Strategies on Enhancement of EFL Students' Speaking Skill: Does Critical Thinking Matter, Journal of English Language Studies 4(2) 2019 120-139. DOI: http://dx.doi.org/10.30870/jels.v4i2.6100

[7] I.G.A.M. Sukelasmini, The Implementation Of Think Pair Share (TPS) Type of Cooperative Learning Model to Improve Student's Motivation and Nutrition Science Learning Achievement, Journal of Education Action Research 3(1) 2019 9-15.

DOI: https://doi.org/10.23887/jear.v3i1.17081

[8] R. Sahardin, C.S. Hanum, S.A. Gani, Using Think Pair Share for Writing Descriptive Texts, Jurnal Studies in English Language and Education 4(1) 2017 54-65. DOI: https://doi.org/10.24815/siele.v4i1.7004

[9] H. Putri, Fahriany, N. Jalil, The Influence of Think Pair Share in Enhancing Students' Speaking Ability, Journal of Education, Teaching and Learning 5(1) 2020 67-72. DOI: http://dx.doi.org/10.26737/jetl.v5i1.1551

[10] I.W.D. Winantara, I.N.L. Jayanta, Penerapan Model Pembelajaran TPS untuk Meningkatkan 
Hasil Belajar IPA Siswa Kelas V SDN Mengwitani, Jurnal Ilmiah Sekolah Dasar 1(1) 2017 9-19. DOI: http://dx.doi.org/10.23887/jisd.v1i1.10127

[11] B. Tanujaya, J. Mumu, Implementation of Think Pair Share to Mathematics Instruction, Journal of Education and Learning (EDULEARN) 13(1) 2019 510-517. DOI: http://dx.doi.org/10.11591/edulearn.v13i4.14353

[12] A. Abdul, F.K. Anam, Perception and Response of Islamic Religious Education Teachers to Religious Education Policy During The Covid-19 Pandemic, Journal of Islamic Education 6 (2020) 1-10.

DOI:

https://doi.org/10.35891/amb.v6i1.2400

[13] F. Razak, The effect of Cooperative Learning on Mathematics Learning Outcomes Viewed From Students' Learning Motivations, Journal of Research and Advances in Mathematics Education 1(1) 2016 49-55. DOI: https://doi.org/10.23917/jramathedu.v1i1.1785

[14] M. Saragih, Yusnadi, Alesyanti, The Influence of Cooperative Learning Models of Think Pair Share Types and Social Attitudes Towards Learning Outcomes Theme of Deliberation in The Contents Of Learning of Student Citizenship Education in Class V of Medan Experimental SDN, Budapest International Research and Critics Institute-Jurnal (BIRCI-Journal) Humanities and Social Sciences 3(1) 2020 511521.

DOI: https://doi.org/10.33258/birci.v3i1.801

[15] P. Siagian, Improvement High Order Think Skill with Think Pair and Share Learning in Social Arithmetic of The School of Medan, Advances in Social Sciences Research Journal 6(6) 2019 6880. DOI: https://doi.org/10.14738/assrj.66.5821

[16] A. Supraba, The Application of Think Pair Share Strategy in Improving Student's Speaking Ability, Journal on English Language Teaching and Learning Linguistics and Literature 6(2) 2018 19-27.

DOI: https://doi.org/10.24256/ideas.v6i2.510

[17] M. Kurjum, A. Muhid, M. Thohir, Think Pair Share Model As Solution to Develop Students' Critical Thinking Is Islamic Studies: Is It Effective?, Cakrawala Pendidikan 39(1) 2020 144-155.

DOI: https://doi.org/10.21831/cp.v39i1.28762
[18] M.L. Syafii, Using The Think Pair Share Strategy to Increase Students Active Involvement and to Improve Their Speaking Ability, Indonesia Journal of English Education 5(1) 2018 61-80. DOI: https://doi.org/10.15408/ijee.v5i1.7679

[19] D. Sari, The Effectiveness of Think Pair Share in Improving Engineering Departement Students Speaking Skill, Journal of English Language and Education 2(1) $2016 \quad$ 18-25. DOI: https://doi.org/10.26486/jele.v2i1.215

[20] Hetika, I. Farida, Y.P. Sari, Think Pair Share As Method to Improve Student's Learning Motivation and Learning Achivement, Journal Dinamika Pendidikan 12(2) 2017 125-135. DOI: https://doi.org/10.15294/dp.v12i2.13561 